\section{The Private-Sector Financing of Public Higher Education Infrastructure}

\section{NORMAN LAROCQUE}

Norman LaRocque is a public policy consultant and adviser to the Education Forum. He is based in Wellington, New Zealand. Address: PO Box 22-282, Khandallah, Wellington 6441, New Zealand. E-mail: norman.larocque@xtra.co.nz.

IHE devotes a column in each issue to a contribution from PROPHE, the Program for Research on Private Higher Education, headquartered at the University at Albany. See http://www.albany.edu/dept/eaps/prophe/.

$\mathrm{O}$ ne of the key trends in recent years has been the growth of private participation in higher education. The most common form of private participation in higher education is the delivery of education services by private colleges and universities. The Program for Research on Private Higher Education (PROPHE) documents that the private sector represents around 25 to 30 percent of global higher education enrollments, although this average masks significant differences across countries and regions. While private higher education represents hefty enrollments in East Asia and Latin America, it is much less weighty in western Europe and the Middle East.

The delivery of education to students in the "traditional" manner represents the bulk of private participation in higher education. However, many other forms exist-including the provision of information (e.g., university rankings such as the Australian Good Universities Guide and the Macleans Guide to Canadian Universities), the regulation of quality (e.g., privately operated accreditation schemes) and private finance initiatives (PFIs).

\section{Private Finance In itiatives}

PFIs are an increasingly common form of public-private partnerships used by governments to procure social infrastructure. Under the most common form of these initiatives, the government makes contracts with the private sector for the finance, design, construction, and operation of infrastructural assets such as schools, university hostels, hospitals, and roads. Although PFIs can be structured in a variety of ways, they do share a number of characteristics: (I) the government continues to deliver so-called core services such as teaching or research; (2) the private-sector partner operates the infrastructure (e.g., hostel or research laboratory) under a long-term con- tract-typically 25 to 30 years, and at the end of the contract period, the asset is turned over to the government agency; (3) contracts are often bundled, with the private sector taking on several functions; and (4) contracts include a performance element-ongoing payments to the private operator are subject to agreed performance standards.

There are a number of examples of PFI-type arrangements in the education sector, although the bulk of these are at the compulsory school level. Several countries (the United Kingdom, Germany, the Netherlands, Ireland, Canada, and Australia) have undertaken PFIs at the compulsory school level. At the postcompulsory level, three developed countriesthe United Kingdom, Ireland, and Australia-have made the greatest use of PFIs. The UK program is the largest infrastructure-related public-private partnership program in the world, with 166 education projects valued at over $£ 5.8$ billion as of December 2006. Just over 20 percent of these projects, valued at $£ 669$ million, have been in UK higher and further education sectors. The largest projects have involved the development of hostels and a sports and leisure facility at the University of Hertfordshire ( $£$ I90 million).

The government of Ireland has used PFIs for a small number of projects at the postcompulsory level, including the National Maritime College of Ireland (58 million euros) and the Cork School of Music (6o million euros). In Australia, the two most significant PFI examples are the Southbank Education and Training Precinct in the State of Queensland (AU \$550 million) and the Swinburne University of Technology (AU\$60 million) project in the State of Victoria.

Among developing countries, Mexico and South Africa are using infrastructure public-private partnerships in education.

Among developing countries, Mexico and South Africa are using infrastructure public-private partnerships in education. Under the Mexican model-Proyectos para Prestación de Servicios-the government makes contracts with private providers for assets and services in health, education, and transport. Twenty-eight projects are being developed in these three sectors, including 5 polytechnic colleges. Currently, the Mexican government is piloting this model in the construction of a new campus for the University of San Luis Potosi, with an expected \$US30 million investment. The project is expected to expand the university's enrollment capacity from I,500 to 5,000 students by 2010 .

Little evidence exists of the benefits of PFIs in education, although studies carried out by, among others, the UK Treasury and the New South Wales Treasury suggest that they can reduce costs and improve the timeliness of infrastructure delivery relative to traditional forms of procurement. Proponents also argue that PFIs allow organizations to focus 
on core business, overcome operating restrictions such as inflexible salary scales, and facilitate the introduction of innovative forms of service delivery.

Skeptics argue that the high cost of borrowing for the private sector, as well as high setup and contract monitoring costs, mean that PFIs can be expensive relative to traditional forms of procurement, especially for small projects. Poor specification of capital needs, flawed contract design, and weak monitoring of projects can also expose the government to significant financial and operational risks, thus negating one of the main intended benefits of PFIs. To overcome these, governments must invest considerable resources in developing standardized contracting processes and resources, as well as capacity building of staff.

\section{CONCLUSION}

PFIs can play a useful public policy role-particularly in countries where considerable investment is required to provide higher education institutions with 2Ist-century teaching and research infrastructure. They can contribute, albeit indirectly, to increasing student access and improving the teaching and research environment. To the extent that they reduce costs, they can also stretch tight government budgets. At the same time, their influence should not be overstated as they do not directly affect the delivery of teaching and the conduct of research. It is likely that the more significant gains from private participation arise from the delivery of "core" services, rather than from infrastructure and maintenance.

We need to know more about the potential impact of PFIs in higher education. More rigorous studies of their impact in higher education and elsewhere-as in other sectors-would be a welcome antidote to debates that are too often clouded by philosophical and ideological differences.

\section{The US Government and}

\section{Accreditation: Extraordinary}

\section{Attention}

\section{JUdith S. EATON}

Judith S. Eaton is president of the Council for Higher Education Accreditation in Washington, DC, USA. E-mail: eaton@chea.org.

$\mathrm{U}^{\mathrm{s}}$ S accreditation is usually a below-the-radar and even nonissue for federal policymakers in Washington, DC. These days, however, accreditation does draw extensive attention from the federal government. Accreditation is one of the few levers allowing the federal government to force change in higher education. For the past 55 years, government has turned to nongovernmental accrediting organizations as reliable authorities on the quality of higher education institutions and programs. As part of sustaining this relationship, the federal government has set standards or requirements by which it reviews and approves the accreditors on which it relies-a process called "recognition." Institutions and programs must maintain accreditation from these federally recognized organizations to be eligible for some \$IOo billion annually in federal funding for student grants and loans, research, and other program funds. Federal criteria imposed on accrediting organizations ultimately become requirements for institutions.

\section{The Commission on the Future of Higher Education}

The focus on accreditation sharpened after the United States Secretary of Education's Commission on the Future of Higher Education, a group of approximately 20 higher education, business, and other leaders, was convened in 2005 to review higher education, including accreditation. The commission's mandate was to recommend changes to the Department of Education about what higher education needs to do to meet future challenges.

In the final report released in September 2006, the commission was quite critical of the state of US accreditation and recommended how this self-regulatory enterprise might be changed. The commission focused on higher education as material gain to students and international competitiveness. The deliberations judged accreditation primarily by the extent to which it reinforced the value of a collegiate experience as a tangible benefit: jobs, mobility, and economic gain. Accreditation was found wanting.

\section{Key ACCREditation Issues}

The commission, following its critique of accreditation, elaborated its call for more accountability and transparency. Accreditation should provide more evidence about student learning outcomes and institutional performance. This evidence needs to be the basis for judgments about quality and accredited status. Accreditation is to develop firm standards to which all institutions would be held accountable, creating comparisons among institutions. The accrediting community needs to take steps to encourage standardized testing as a key means to determine quality. The commission raised questions about the transparency of accreditation itself-that is, whether the public receives easily accessible and reliable information about judgment of quality. Repeatedly the commission asked "What is accreditation doing to assist the public in making good decisions about attending a college or university?"

These issues are not unique to the United States. Many of these topics are also shaping discussions about accreditation and quality assurance in some other countries. The Bologna process in Europe and work on quality assurance in, for example, Turkey, Egypt, South America, and South Africa all focus 